\title{
PENINGKATAN KOMPETENSI MENULIS CERITA PENDEK MELALUI TEKNIK TRANSFORMASI TEKS PUISI DAN CO-CREATIVE WRITTING
}

\author{
Hartono, Suroso, dan Dwi Budiyanto \\ email: hartono-fbs@uny.ac.id
}

\begin{abstract}
Abstrak
Menuliskreatif merupakan keterampilan yang dapatberkontribusibagi pengembangan kemampuan berbahasa. Penelitian ini bertujuan untuk meningkatkan kompetensi mahasiswa dalam menulis cerita pendek melalui teknik transformasi teks puisi dan cocreative writing. Penelitian ini melibatkan 18 orang mahasiswa Jurusan Pendidikan Bahasa dan Sastra Indonesia Fakultas Bahasa dan Seni Universitas Negeri Yogyakarta sebagai subjek penelitian dan seorang dosen pengampu mata kuliah Menulis Sastra sebagai kolaborator peneliti. Jenis penelitian ini merupakan penelitian tindakan kelas dengan menerapkan dua siklus dengan lima kali pertemuan selama pengambilan data penelitian. Pengumpulan data dilakukan melalui teknik observasi, wawancara, dan penyebaran kuisioner untuk kemudian dilakukan kondensasi data, penyajian data, dan penarikan kesimpulan dari data kualitatif yang diperoleh. Kemampuan mahasiswa dalam menulis cerita pendek diperoleh melalui tes menulis cerita pendek yang kemudian dianalisis secara deskriptif kuantitatif. Berdasarkan analisis, diperoleh kesimpulan sebagai berikut. Pertama, penerapan teknik transformasi teks puisi dan co-creative writing dapat meningkatkan efikasi diri mahasiswa, mengembangkan kesadaran kolaborasi dalam menulis cerita pendek, dan membangun suasana perkuliahan menulis sastra yang aktif dan dinamis.Kedua, peningkatan skor rerata setiap aspek kompetensi menulis cerita pendek dari siklus ke siklus memperlihatkan bahwa penerapan teknik transformasi teks puisi dan co-creative writing dapat meningkatkan kompetensi menulis cerita pendek di kalangan mahasiswa. Teknik ini terutama sangat membantu dalam mengembangkan kemampuan untuk menggali ide dan imajinasi penulisan cerita pendek. Mahasiswa menjadi terlatih untuk melakukan ekspansi cerita, modifikasi dan variasi, atau konversi cerita.
\end{abstract}

Kata kunci: menulis kreatif, transformasi teks puisi, efikasi diri, menulis kolaboratif

\section{INCREASING COMPETENCE OF SHORT STORIES WRITING THROUGH POETRY TEXT TRANSFORMATION AND CO-CREATIVE WRITING TECHNIQUES}

\begin{abstract}
Creative writing is a skill that is expected to contribute to the development of language skills. This study aimed to improve students' competence in writing short stories throughpoetry texts transformation and co-creative writing techniques. The study
\end{abstract}


involved 18 students of the Department of Language and Literature Education, Faculty of Language and Arts, Yogyakarta State University as research subjects and a lecturer who teaches Literature as a research collaborator. The studywas a classroom action research by applying two cycles with five meetings during the research data collection. Data collection was carried out through observation, interviews, and filling out questionnaires followed by data condensation, data display, and drawing conclusions from the qualitative data obtained.Students' ability in writing short stories was obtained through a short story writing test which was then analyzed using descriptivequantitative analysis. The following research results were obtained. First, the application of poetry texts transformation and co-creative writing techniques increased student self-efficacy, developed collaborative awareness in writing short stories, and built an active and dynamic literary writing lecture atmosphere. Second, the increase in the mean score of each aspect of competency in writing short stories from cycle to cycle showed that the application of the poetry texts transformation and co-creative writing techniques improved the competence of writing short stories among students. This technique was especially helpful in developing the ability to explore ideas and imagination in writing short stories. Students became trained to do story expansion, modification and variation, or story conversion.

Keywords: creative writing, poetry texts transformation, self-efficacy, collaborative writing

\section{PENDAHULUAN}

Pembelajaran menulis cerita pendek sebenarnya terbentuk dari sebuah proses yang kompleks dengan menyertakan kompetensi pengarang yang tidak sederhana. Ada daya komprehensi terhadap realitas yang harus dimiliki seorang pengarang, sekaligus juga daya kreasi yang berkaitan dengan kompetensi menulis kreatif. Dengan demikian, proses pembelajaran menulis sastra seharusnya mendapat perhatian lebih. Terlebih pembelajaran menulis cerita pendek sering dimanfaatkan untuk meningkatkan kemampuan berbahasa peserta didik (Khatib \& Seyyedrezaei, 2017: 177; Rahman \& Arju, 2013; Pardede, 2011). Aktivitas menulis sastra juga mengarahkan para peserta didik untuk meningkatkan kemampuan berpikir kreatif dan kritis, mengembangkan daya imajinasi, menetapkan tujuan hidup yang tepat, dan kemampuan komunikasi mereka (Masie, dkk., 2018: 391). Sayangnya, secara umum, pembelajaran menulis - termasuk menulis sastra kurang ditangani secara serius (Syamsi, 2012: 2). Akibatnya, proses pembelajaran menulis sastra masih dianggap sebagai aktivitas yang sulit bagi para siswa.

Realitas tersebut sesuai dengan sejumlah penelitian bahwa para peserta didik masih kesulitan dalam menulis karya sastra. Kesulitan-kesulitan tersebut, antara lain kesulitan dalam penggalian dan pengembangan ide, penyusunan plot yang proporsional, pembuatan lead cerita yang menarik, penyusunan akhir cerita, 
penggarapan konflik dan klimaks cerita, serta penciptaan suspensi (Sayuti, dkk., 2008: 23; Dimililer, dkk., 2020: 189). Kesulitan-kesulitan tersebut sebagian besar berkaitan dengan teknik penulisan sastra.

Hasil penelitian Sayuti, dkk (2008) ternyata memiliki kesamaan dengan observasi awal terhadap mahasiswa Program Studi Pendidikan Bahasa dan Sastra Indonesia, FBS UNY. Temuan mengenai kesulitan menulis sastra terjadi pada mahasiswa kelas $2 \mathrm{~J}$ yang mengambil matakuliah Menulis Sastra pada semester genap, sebanyak 2 SKS. Berdasarkan refleksi terhadap pembelajaran Menulis Sastra pada semester genap tahun 2018 yang dilakukan pada pertengahan Maret 2018 diketahui bahwa hampir 65\% mahasiswa merasa tidak mampu menulis karya sastra. Sebagian besar mahasiswa menyatakan kesulitan menemukan ide, sering kehilangan gagasan saat menulis, dan menganggap hasil tulisannya jelek. Anggapan bahwa tulisan mahasiswa jelek menyebabkan mereka merasa tidak layak memublikasikan karyanya.

Kondisi ini sangat menghambat pencapaian kompetensi mahasiswa dalam menulis sastra. Berdasarkan pembacaan terhadap karya mahasiswa juga ditemukan bahwa kebanyakan ide tulisan mereka sangat klise, cerita tidak fokus dan cenderung kurang padat, awal cerita yang tidak menarik, dan akhir cerita yang tidak kuat. Jadi, di samping masalah-masalah penguasaan teknik menulis, terdapat permasalahan mendasar dalam diri mahasiswa. Masalah tersebut antara lain adalah daya komprehensi serta efikasi diri (self efficacy) yang rendah.
Efikasi diri merupakan keyakinan peserta didik terhadap kemampuannya untuk berhasil sehingga dapat menyelesaikan tugas dan meningkatkan kemampuannya dengan lebih baik (Bandura, 2010: 1). Dalam konteks menulis, efikasi diri mendukung secara positif kemampuan peserta didik dalam menulis (writing performance) (Tanyer, 2015: 39). Jika efikasi diri dan motivasi berprestasi meningkatkan kompetensi menulis, kecemasan dalam menulis ternyata menghambat perkembangan kemampuan seseorang dalam menulis (Sabti, dkk., 2019: 1). Kemampuan menulis kreatif yang masih terbatas dan adanya beban penulisan secara individu menjadi penyebab kecemasan dalam menulis serta rendahnya tingkat efikasi diri peserta didik. Oleh karena itu, upaya meningkatkan efikasi diri dalam menulis harus menjadi prioritas dalam pembelajaran menulis kreatif.

Selain itu, keragaman kemampuan dalam kelas menulis sastra harus dapat dimanfaatkan dengan baik. Para siswa harus berkolaborasi untuk meningkatkan kompetensi mereka dalam menulis sastra. Selain itu, diperlukan pula teknik yang dapat menumbuhkan kerjasama antar mahasiswa dalam mencapai kompetensi menulis sastra, terutama cerita pendek. Teknik yang dimaksud adalah teknik kolaboratif dalam menulis kreatif (co-creative writing). Menulis kolaboratif bermanfaat dalam memperbaiki tulisan, memunculkan ide, membangun emosi positif (mengurangi stres), dan memberikan efek sosial, terutama dalam menjalin kerjasama (Chen \& Yu, 2019: 1; Debao \& Blum, 2013; Wigglesworth \& Storch, 2009). 
Tidak saja bermanfaat dalam menggali ide, aktivitas menulis secara kolaboratif juga menumbuhkan kerjasama antar peserta didik melalui pemberian umpan balik (Storch, 2005: 153). Dengan demikian, teknik kolaboratif dalam menulis kreatif (co-creative writing) tidak saja dapat meningkatkan kompetensi dalam menulis, tetapijuga menumbuhkan afeksi positif dalam menulis kreatif.

Untuk semakin memperkuat kemampuan mahasiswa dalam menulis cerita pendek, perlu pula dirancang pula sebuah teknik perkuliahan menulis sastra yang mampu menantang mahasiswa untuk mengeksplorasi ide-ide kepenulisan secara bebas dan kreatif. Teknik transformasi teks puisi, terutama puisi naratif, dimungkinkan dapat memantik mahasiswa untuk mengeksplorasi ide penulisan. Teks puisi ditransformasikan menjadi teks fiksi yang baru dan kreatif. Ide dasar dalam teks puisi naratif akan memudahkan mahasiswa untuk memperoleh ide penulisan cerita pendek. Namun, ide dasaritu harus dikembangkan lagi menjadi karya sastra yang berbeda.

Dalam hal ini, mahasiswa ditantang untuk melakukan interpretasi sekaligus membangun imajinasi untuk menghasilkan karya yang berbeda, baik berbeda dalam pengembangan cerita, sudut pandang penceritaan, alur, pengembangan konflik, dan sebagainya.

Dengan demikian, teknik transformasi teks puisi (naratif) dan kolaboratif dalam menulis kreatif diharapkan mampu meningkatkan kompetensi mahasiswa dalam menulis cerita pendek. Penelitian ini bertujuan untuk meningkatkan kualitas pembelajaran, yaitu pembelajaran menulis cerita pendek dalam perkuliahan Menulis Sastra, baik secara proses maupun produk. Secara proses, penelitian ini ditujukan untuk meningkatkan efikasi diri mahasiswa. Sementara dari sisi produk, ia diharapkan meningkatkan kompetensi menulis cerita pendek.

\section{METODE}

Jenis penelitian ini merupakan penelitian tindakan. Adapun model penelitian tindakan yang digunakan adalah model Kemmis and McTaggart (1988) dari Burn (2010: 9), dengan rangkaian tindakan berupa perencanaan (planning), tindakan (acting), observasi (observing), dan refleksi (reflecting). Subjek penelitian adalah mahasiswa Program Studi Pendidikan Bahasa dan Sastra Indonesia FBS UNY semester 2 kelas 2J. Kelas ini terdiri atas 18 orang mahasiswa dengan satu orang dosen Menulis Sastra sebagai kolaborator.

Pengumpulan data dilakukan dengan observasi, kuisioner, wawancara, dan tes menulis cerita pendek. Observasi, wawancara, dan kuisioner dilakukan untuk mengumpulkan data yang berupa respon dan tanggapan mahasiswa terhadap pelaksanaan tindakan. Sementara itu, pengumpulan data dengan tes menulis dilakukan untuk memperoleh data kompetensi menulis sastra.

Kriteria keberhasilan penelitian ini mencakup keberhasilan secara proses dan produk. Keberhasilan secara proses terlihat dari adanya (1) peningkatan efikasi diri mahasiswa, (2) kesadaran kerjasama untuk meningkatkan kompetensi menulis cerita pendek, dan (3) peningkatan antusias mahasiswa dalam 
perkuliahan. Keberhasilan secara produk terlihat dari peningkatan kemampuan menulis cerita pendek. Kemampuankemampuan tersebut antara lain berkaitan dengan (1) teknik mengolah ide, (2) kekuatan alur, (3) penggunaan sudut pandang (point of view), dan (4) mekanik kebahasaan.

Teknik analisis data dalam penelitian ini mengacu pada metode dari Miles, Huberman, dan Saldana (2014: 10-12), yaitu kondensasi data, penyajian data, dan verifikasi data atau penyimpulan. Pertama, data diseleksidan diabstraksikan menjadi informasi bermakna berdasarkan tujuan penelitian. Data yang dikondensasi tersebut berasal dari catatan lapangan, observasi, dan kuisioner. Kedua, data yang telah terkondensasi disajikan dalam bagan dan paparan naratif sehingga memudahkan untuk dilakukan pengambilan kesimpulan. Ketiga, tahap penarikan kesimpulan yang dilakukan untuk mengetahui kemajuan implementasi tindakan. Setelah itu dilakukan verifikasi terhadapnya.

Data kuantitatif untuk mengetahui kompetensi menulis sastra mahasiswa menggunakan rubrik penilaian menulis yang diadaptasi dari Jacobs, dkk. (Weigle, 2002: 116) dan Nurgiyantoro (2010: 488).

Rubrik penilaian terdiri atas (1) pengolahan ide dan imajinasi, (2) kekuatan alur, (3) pemanfaatan sudut pandang (point of view), (4) kelancaran bercerita, dan (6) mekanik kebahasaan. Data berupa skor tugas menulis cerita pendek dianalisis dengan menggunakan analisis deskriptif kualitatif.

\section{HASIL PENELITIAN DAN PEMBAHASAN}

Hasil Penelitian

Untukmengetahuikondisiperkuliahan menulis sastra dilakukan wawancara, observasi, dan pretes di kelas 2J semester genap Program Studi Pendidikan Bahasa dan Sastra Indonesia FBS UNY angkatan 2018/2019 yang mengikuti mata kuliah Menulis Sastra. Hasil wawancara dan observasi memperlihatkan bahwa mahasiswa tidak memiliki minat terhadap mata kuliah Menulis Sastra. Mereka beranggapan tidak memiliki kemampuan yang cukup untuk menulis cerita pendek. Ketika mendapat gambaran tentang tugas dan proyek penulisan cerita pendek, para mahasiswa mengekspresikan penolakan dan keluhannya. Mereka merasa terbebani dan menganggap tidak mampu menghadapi tantangan menulis cerita pendek. Selama proses observasi perkuliahan, mereka cenderung terlihat diam, kurang responsif, dan tidak memperlihatkan minat yang tinggi. Temuan tersebut mengindikasikan bahwa para mahasiswa memiliki efikasi diri (self efficacy) yang rendah. Selain itu, berdasarkan pembacaan terhadap cerita pendek karya mahasiswa ditemukan bahwa kebanyakan ide tulisan mereka sangat klise, cerita tidak fokus dan cenderung kurang padat, awal cerita tidak menarik, dan akhir cerita tidak digarap dengan kuat.

Setelah perlakuan tindakan dengan menerapkan teknik co-creative Writing dan transformasi teks puisi terjadi perubahan dalam efikasi diri mahasiswa. Mahasiswa mulai terlihat antusias dan bersemangat mengikuti perkuliahan. Selain itu, kompetensi mahasiswa dalam menulis 
cerita pendek secara berangsur mengalami peningkatan. Aspek yang mengalami peningkatan tersebut, antara lain aspek pengembangan ide dan penggarapan alur cerita, pemanfaatan sudut pandang, dan mekanik kebahasaan.

Pada pelaksanaan siklus I, mahasiswa mulai terlihat lebih antusias, bersemangat, terbuka untuk berbagi ide, apresiatif terhadap karya orang lain, dan terbuka terhadap kritik. Selain itu, mereka menjadi lebih tertantang untuk menuntaskan tugas-tugas penulisan sastra. Mahasiswa juga mulai berani mengeksplorasi ide penulisan cerpen sebagai akibat dari tantangan untuk mentransformasikan teks puisi naratif menjadi cerita pendek secara kolaboratif.

Selain capaian keberhasilan secara proses, ditemukan beberapa kekurangan yang harus diperbaiki pada siklus berikutnya. Beberapa kelompok mahasiswa masih mengikuti pola umum cerita dalam teks puisi. Ini artinya, pengembangan ide dan alur cerita perlu mendapat penguatan lebih. Hal ini terlihat dari sejumlah pertanyaan yang dikemukakan mahasiswa tentang bagaimana teks puisi naratif dikembangkan secara bebas menjadi cerita pendek. Di samping itu, penguasaan mahasiswa terhadap mekanik kebahasaan masih perlu ditingkatkan lagi. Pada siklus II semakin memperlihatkan hasil bahwa teknik transformasi teks puisi dan teknik cocreative writing dapat meningkatkan kompetensi menulis cerita pendek. Secara proses mahasiswa mengalami peningkatan dalam hal (1) efikasi diri dalam menulis cerita pendek, (2) kesadaran untuk bekerjasama dan memberikan dukungan bagi teman sebaya, dan (3) sikap antusias dalam perkuliahan. Selain itu, terjadi pula perbaikan cerita pendek hasil karya mahasiswa. Hal ini memperlihatkan terjadinya keberhasilan secara produk. Mahasiswa mengalami peningkatan dalam kompetensi menulis cerita pendek, terutama dalam (1) teknik mengolah ide, (2) penyusunan alur cerita, (3) penggunaan sudut pandang (point of view), dan (4) mekanik kebahasaan. Capaincapain tersebut diperlihatkan dalam tabel berikut ini.

Tabel 1 Peningkatan Proses Kompetensi Menulis Cerita Pendek

\begin{tabular}{|c|c|c|c|c|}
\hline \multirow[b]{2}{*}{ Aspek } & \multirow[b]{2}{*}{ Indikator } & \multicolumn{3}{|c|}{ Siklus } \\
\hline & & $\begin{array}{l}\text { Sebelum } \\
\text { Tindakan }\end{array}$ & 1 & 2 \\
\hline \multirow{6}{*}{$\begin{array}{l}\text { Efikasi Diri } \\
\text { Mahasiswa }\end{array}$} & 1. Mahasiswa antusias dalam praktik menulis cerita pendek & 4 & 10 & 17 \\
\hline & $\begin{array}{l}\text { 2. Mahasiswa terlihat bersemangat menerima tantangan baru } \\
\text { dalam menulis cerita pendek }\end{array}$ & 4 & 10 & 16 \\
\hline & $\begin{array}{l}\text { 3. Mahasiswa berusaha menyelesaikan tugas menulis cerita } \\
\text { pendek }\end{array}$ & 8 & 12 & 17 \\
\hline & $\begin{array}{l}\text { 4. Mahasiswa terlihat terbebani dengan aktivitas menulis } \\
\text { cerita pendek }\end{array}$ & 14 & 6 & 1 \\
\hline & $\begin{array}{l}\text { 5. Mahasiswa menolak tantangan baru dalam menulis cerita } \\
\text { pendek }\end{array}$ & 14 & 2 & 1 \\
\hline & $\begin{array}{l}\text { 6. Mahasiswa enggan menuntaskan tugas menulis cerita } \\
\text { pendek }\end{array}$ & 12 & 2 & 0 \\
\hline
\end{tabular}

Peningkatan Kompetensi Menulis Cerita Pendek Melalui Teknik Transformasi Teks Puisi... 


\begin{tabular}{llccc}
\hline \multirow{2}{*}{ Aspek } & \multicolumn{1}{c}{ Indikator } & \multicolumn{3}{c}{ Siklus } \\
\cline { 3 - 5 } & \multicolumn{1}{c}{$\begin{array}{c}\text { Sebelum } \\
\text { Tindakan }\end{array}$} & $\mathbf{1}$ & $\mathbf{2}$ \\
\hline & $\begin{array}{l}\text { 1. Mahasiswa bekerjasama dalam kelompok } \\
\text { 2. Mahasiswa terbuka terhadap kritik dan masukan atas } \\
\text { karyanya }\end{array}$ & - & 12 & 17 \\
Kemampuan & 3. Mengapresiasi karya teman sebaya & 4 & 10 & 16 \\
Kolaborasi & 4. Mahasiswa tidak aktif & 5 & 12 & 17 \\
& $\begin{array}{l}\text { 5. Mahasiswa bekerja secara soliter/tidak terlibat dalam } \\
\text { aktivitas kelompok }\end{array}$ & 14 & 3 & 1 \\
& 6. Mahasiswa tertutup terhadap masukan & 9 & 3 & 1 \\
& & 13 & 2 & 0 \\
\hline
\end{tabular}

Tabel 2 Nilai rata-rata kompetensi menulis cerpen

\begin{tabular}{ccc}
\hline Pra-tindakan & Siklus I & Siklus II \\
\hline 8,94 & 11,94 & 19,17 \\
\hline
\end{tabular}

Berdasarkan tabel 2 terlihat terjadi peningkatan kompetensi mahasiswa dalam menulis cerita pendek setelah dilakukan tindakan dengan teknik transformasi teks puisi dan teknik cocreative writing. Nilai skor rerata sebelum tindakan mengalami kenaikan 3,00 setelah siklus I dan 9,23 setelah siklus II. Peningkatan kompetensi tersebut terlihat terutama pada pengolahan ide dan daya imajinasi mahasiswa untuk mentransfor- masikan teks puisi (naratif) menjadi cerita pendek. Selain itu, kemampuan menyusun alur cerita dan memanfaatkan sudut pandang penceritaan juga mengalami peningkatan. Secara teknis kelancaran bercerita dan mekanik kebahasaan juga mengalami perbaikan. Secara detail, pencapaian kelima aspek kompetensi menulis cerita pendek tersebut tersajikan dalam tabel berikut ini.

Tabel 3 Pencapaian aspek kompetensi menulis cerita pendek

\begin{tabular}{lccc}
\hline \multirow{2}{*}{ Aspek Penilaian } & \multicolumn{3}{c}{ Nilai rata-rata } \\
\cline { 2 - 4 } & $\begin{array}{c}\text { Sebelum } \\
\text { tindakan }\end{array}$ & Siklus I & Siklus II \\
\hline Pengolahan ide dan imajinasi & 1,39 & 3,61 & 4,11 \\
Kekuatan alur cerita & 1,78 & 2,67 & 3,89 \\
Penyusunan sudut pandang (point of view) & 2,06 & 2,44 & 3,89 \\
Kelancaran bercerita & 1,94 & 2,28 & 3,44 \\
Mekanik kebahasaan & 1,78 & 1,94 & 3,83 \\
\hline
\end{tabular}


Pada siklus I terjadi peningkatan pada aspek pengolahan ide dan imajinasi. Peningkatan nilai rata-rata aspek ini sebesar 2,22. Hal ini memperlihatkan bahwa teknik transformasi teks puisi yang dipadukan dengan co-creative writing dapat merangsang mahasiswa untuk memikirkan sejumlah alternatif pengembangan cerita. Mahasiswa secara aktif terdorong untuk mendiskusikan pengembangan sudut pandang yang berbeda dari teks puisi yang dipilih untuk memantik ide penulisan. Aspek pengolahan ide dan imajinasi terlihat sebagai aspek yang paling dominan mengalami peningkatan dibandingkan aspek-aspek yang lain, seperti kekuatan alur cerita, penyusunan sudut pandang, kelancaran bercerita, dan mekanik kebahasaan. Hal tersebut sekaligus memperlihatkan kondisi siklus I yang menunjukkan bahwa kemampuan mekanik kebahasaan masih menjadi persoalan.

Pada siklus II mekanik kebahasaan dan aspek lainnya telah mengalami peningkatan. Aspek pengolahan ide dan imajinasi masih menjadi aspek yang mengalami peningkatan terbesar. Jika dibandingkan dengan pra-tindakan, aspek ini mengalami peningkatan nilai rata-rata sebesar 2,72. Aspek kekuatan alur cerita sebesar 2,11. Kenaikan nilai rata-rata aspek penyusunan sudut pandang sebesar sebesar 1,83. Kenaikan nilai rata-rata aspek kelancaran bercerita sebesar 1,50. Sementara itu, kenaikan nilai rata-rata aspek mekanik kebahasaan sebesar2,05. Capaianinimengindikasikan bahwa tindakan yang diberikan setelah siklus kedua mampu meningkatkan kompetensi menulis cerita pendek mahasiswa. Oleh karena itu, peneliti dan kolaborator memutuskan untuk menghentikan siklus.

Untuk memudahkan interpretasi, nilai skor atas aspek kompetensi menulis cerita pendek dari tugas menulis mahasiswa dikonversikan dalam lima kategori, yaitu "sangat buruk", "buruk", "baik", dan "sangat baik." Tabel konversi tersebut tersajikan sebagai berikut.

Tabel 4 Tabel konversi skor menulis cerita pendek

\begin{tabular}{llccc}
\hline \multirow{2}{*}{ Kelas Interval } & \multicolumn{1}{c}{ Kategorisasi } & \multicolumn{3}{c}{ Frekuensi } \\
\cline { 3 - 5 } & & Pre-tes & Siklus I & Siklus II \\
\hline $20-25$ & Sangat Baik & 0 & 0 & 5 \\
$15-19$ & Baik & 0 & 3 & 13 \\
$10-14$ & buruk & 8 & 11 & 0 \\
$5-9$ & Sangat buruk & 11 & 4 & 0 \\
\hline
\end{tabular}

Peningkatan Kompetensi Menulis Cerita Pendek Melalui Teknik Transformasi Teks Puisi... 
Berdasarkan tabel 4 terlihat sebaran kemampuan mahasiswa dalam menulis cerita pendek dalam kategori "sangat buruk", "buruk", "baik", dan "sangat baik." Sebelum dikenakan tindakan kemampuan mahasiswa dalam menulis cerita pendek berada dalam kategori "sangat buruk" dan "buruk." Setelah pelaksanaan tindakan, terlihat terjadi perubahan kompetensi mahasiswa dalam menulis cerita pendek. Pada akhir siklus kedua, telah terdapat lima orang mahasiswa dalam kategori "sangat baik" dan 13 orang mahasiswa dalam kategori "baik."

Hal ini mengindikasikan bahwa penerapan teknik transformasi teks puisi (naratif) dan co-creatif writing mendorong mahasiswa untuk meningkatkan efikasi diri, sikap antusias, dan kemampuan berkolaborasi untuk meningkatkan kompetensi menulis cerita rakyat. Peningkatan aspek afeksi mahasiswa, terutama dalam hal efikasi diri, sikap antusias, dan kemampuan berkolaborasi meningkatkan aspek kompetensi dalam menulis, terutama pengolahan ide dan imajinasi, kekuatan alur cerita, penyusunan sudut pandang, kelancaran bercerita, dan mekanik kebahasaan. Tindakan sebanyak dua siklus dengan lima kali pertemuan berhasil mengembangkan efikasi diri mahasiswa dan kemampuan kerjasama, kompetensi menulis sastra, dan memperbaiki suasana perkuliahan selama pembelajaran berlangsung.

\section{Pembahasan}

Penerapan teknik transformasi teks puisi dan teknik kolaborasi dalam menulis kreatif (co-creative writing) telah mampu meningkatkan efikasi diri mahasiswa dalam menulis cerita pendek, memperbaiki dan mengondisikan suasana perkuliahan, dan mengembangkan kompetensi mahasiswa dalam menulis cerita pendek. Pada awalnya para mahasiswa menghadapi persoalan serius dalam menulis cerita pendek. Hasil penilaian terhadap karya awal para mahasiswa ditemukan bahwa rata-rata ide tulisan mereka sangat klise, cerita tidak fokus dan cenderung kurang padat, plot tidak tergarap dengan baik, awal cerita yang tidak menarik, dan akhir cerita yang tidak kuat. Kondisi ini memiliki kesamaan dengan yang dipaparkan Dimililer, dkk. (2020: 189). Kondisi ini menjadikan efikasi diri mahasiswa menjadi rendah. Mereka mengalami kecemasan setiap kali berhadapan dengan tugas menulis.

Efikasi diri merupakan keyakinan peserta didik terhadap kemampuannya untuk berhasil sehingga dapat menyelesaikan tugas dan meningkatkan kemampuannya dengan lebih baik (Bandura, 2010). Dörnyei (2001:22-23) menjelaskan bahwa efikasi diri merupakan keyakinan seseorang terhadap kemampuan mereka untuk melakukan tugas-tugas spesifik. Perasaan mampu untuk melakukan sesuatu itulah yang akan menentukan tingkat perhatian, besarnya usaha, sekaligus ketekunan mereka. Dalam konteks menulis cerita pendek, efikasi diri ternyata memperkuat kemampuan menulis peserta didik (writing performance) (Tanyer, 2015: 39). Jika efikasi diri dan motivasi berprestasi meningkatkan kompetensi menulis, kecemasan dalam menulis ternyata menghambat perkembangan kemampuan 
seseorang dalam menulis (Dimililer, 2020: 188). Itulah sebabnya, mahasiswa yang memiliki efikasi diri rendah, kemampuan menulis cerita pendeknya akan stagnan dan tidak berkembang.

Penerapan teknik transformasi teks puisi dan kolaborasi dalam menulis kreatif selama minimal dua siklus ternyata mampu meningkatkan kompetensi mahasiswa dalam menulis cerita pendek. Hal ini terjadi karena beberapa hal. Pertama, teknik co-creative writing menumbuhkan kebersamaan dalam kelompok. Kesadaran ini menjadikan setiap tantangan dalam menulis cerita pendek dapat dihadapi bersama-sama. Meskipun kemampuan menulis bersifat individual, banyak penelitian menyarankan untuk mengenalkan kolaborasi dalam pembelajaran. Melalui kolaborasi, para mahasiswa mendapatkan masukan yang berharga dari orang lain. Hal ini sesuai dengan penelitian Ansarimoghaddam \& Tan (2018: 35-36) bahwa pembelajaran kolaboratif mampu menciptakan kondisi yang memungkinkan para mahasiswa untuk bertukar ide, pengalaman, dan informasi yang memperkaya wawasan sekaligus memberikan solusi atas permasalahan-permasalahan yang dihadapi.

Kedua, teknik transformasi teks puisi dan co-creative writing dalam menulis cerita pendek membangun kesadaran pada mahasiswa bahwa menulis berkaitan dengan daya tahan untuk menghadapi tantangan, bukan sekedar perkara produk tulisan. Pendekatan ini dapat membangun motivasi mahasiswa dalam menulis sastra. Mereka menjadi lebih menikmati setiap proses kepenulisan dan tidak dibebani dengan produk. Hal ini sesuai dengan penelitian Vengadasamy (2002) bahwa para siswa ternyata merasa lebih termotivasi untuk terlibat dalam aktivitas menulis ketika mereka beranggapan bahwa para guru lebih tertarik pada ide dan gagasan daripada ketepatan berbahasa mereka. teknik transformasi teks puisi dan co-creative writing menciptakan kondisi tersebut.

Ketiga, penerapan teknik co-creative writing membentuk suasana pembelajaran menjadi lebih aktif. Inilah yang menyebabkan penerapannya selama dua siklus dalam penelitian ini mampu mengubah sikap mahasiswa yang sebelumnya bersikap apatis menjadi aktif dan antusias dalam perkuliahan. Temuan ini sejalan dengan penelitian yang dilakukan Dabao \& Blum (2013: $365-$ 378) bahwa selain menyebabkan mahasiswa mendapatkan banyak ide dan kemungkinan pengembangan bahasa, kolaborasi dalam menulis lebih banyak memberikan kesempatan untuk berpartisipasi aktif.

Hasil observasi selama tindakan di sikluspertama dankedua memperlihatkan terbentuknya suasana yang aktif dan penuh sikap antusias selama perkuliahan setelah penerapan teknik transformasi teks puisi dan co-creative writing. Berdasarkan tabel 1terdapat 55,6\% mahasiswa yang terlihat antusias dalam praktik menulis cerita pendek di siklus pertama. Jumlah tersebut meningkat menjadi $94,4 \%$ pada siklus kedua. Selain itu, sebanyak $55,6 \%$ orang mahasiswa terlihat bersemangat menerima tantangan baru dalam menulis cerita pendek di siklus pertama. Pada siklus kedua, jumlah tersebut meningkat menjadi 
$88,9 \%$. Data tersebut menunjukkan suasana perkuliahan yang lebih aktif dan dinamis setelah penerapan teknik transformasi teks puisi dan co-creative writing.

Keempat, teknik transformasi teks puisi dan co-creative writing memberikan peluang untuk meningkatkan bentuk dan jenis tantangan dalam penulisan sesuai dengan kemampuan mahasiswa. Proses transformasi teks, sebagaimana dijelaskan Setiartin R (2016: 395) berorientasi pada keaktifan siswa. Secara kooperatif (maha)siswa melakukan pengkajian estetis, pemahaman kritis, dan penuangan kreativitas imajinatif. Ketiga proses tersebut merupakan aktivitas yang menantang bagi daya kreativitas mahasiswa. Inilah yang menyebabkan perubahan sikap mahasiswa dari apatis menjadilebih antusias dalam pelaksanaan siklus pertama dan kedua.

Ketika mahasiswa mulai mengalami peningkatan kompetensi, tantangan yang diberikan dapat ditingkatkan. Peningkatan tantangan dilakukan dengan memilihkan jenis teks puisi yang semakin menantang daya kreativitas mahasiswa. Dalam pandangan Riffatere (1978: 23), proses transformasi teks disebut sebagai hipogram. Sebuah karya dapat merupakan variasi dan modifikasi karya sebelumnya. Dalam konteks menulis cerita pendek dengan teknik transformasi teks puisi, para mahasiswa menjadi lebih tertantang untuk melakukan ekspansi, modifikasi dan variasi, atau konversi.

Selain terjadi perbaikan pada sikap mahasiswa dan suasana perkuliahan, teknik transformasi teks puisi dan cocreative writing mampu meningkatkan kemampuan mahasiswa dalam menulis cerita pendek. Peningkatan kompetensi menulis sastra terjadi dalam beberapa kriteria, yaitu pertama, pengembangan ide penceritaan dan imajinasi. Ketika mahasiswa disodorkan puisi "Tentang Sersan Nurcholis" karya penyair Taufiq Ismail, puisi tersebut lalu dimodifikasi dan dikembangkan menjadi cerpen yang menarik, yang berbeda dengan teks aslinya. Puisi ini berkisah tentang seorang sersan yang menjadi tukang reparasi jam karena kakinya diamputasi akibat perang pada masa revolusi. Setiap siang, di bengkel arlojinya, Sersan Nurcholis sering bersiul. Dia pernah ditawari kartu bekas pejuang, tetapi selalu ditolaknya.

Puisi ini lalu dikembangkan secara bebas oleh mahasiswa berkode P-009, P-015, dan P-018 menjadi cerita yang sama sekali baru berjudul "Berouw". Berouw bercerita tentang seorang bernama Darto yang memiliki toko barang-barang seni. Toko tersebut bernama Berouw. Dahulunya Darto seorang pejuang. Dalam sebuah pertempuran ia bergelut dengan serdadu Belanda bernama Robert van Moedig. Serdadu Belanda tersebut akhirnya dapat dibunuhnya. Belakangan dari ibunya, baru ia ketahui bahwa serdadu Belanda yang dibunuhnya adalah ayahnya sendiri. Ide dasar dari teks puisi dikembangkan secara bebas menjadi cerita yang menarik. Imajinasi mahasiswa memodifikasi teks puisi naratif menjadi cerita pendek yang berbeda.

Kedua, kekuatan alur. Ketika berhadapan dengan puisi naratif, para mahasiswa lalu mendiskusikannya di dalam kelompok. Mereka mematangkan 
ide dan menyusun alur cerita yang sesuai. Salah satu yang dilakukan adalah menciptakan suspensi dan kejutan di bagian akhir cerita. Ini artinya, cara bertutur mahasiswa tidak lagi monoton dan datar. Selain itu, mahasiswa juga mulai mampu mendeskripsikan latar dengan lebih baik. Prinsip showing not telling mulai banyak dimanfaatkan. Ketiga, penentuan sudut pandang penceritaan yang sesuai. Kolaborasi dalam menulis memberikan peluang bagi mahasiswa untuk menentukan sudut pandang penceritaan yang unik dan menarik. Selama dua siklus penelitian dilaksanakan, mahasiswa mulai berani mengeksplorasi sudut pandang (point of view) penceritaan. Ketika disodorkan puisi "Dengan Kata Lain" karya Joko Pinurbo yang berkisah tentang seorang lelaki yang bertemu dengan tukang ojek, yang ternyata adalah guru Sejarahnya dulu, para mahasiswa secara kreatif mendiskusikan sudut pandang penceritaan. Salah satu kelompok menyusun cerita pendek dari sudut pandang motor sang guru yang mengojek tersebut. Benda mati, seperti motor dipersonifikasikan dan seakan dihidupkan menjadi narator dalam cerita pendek.

Keempat, aspek mekanik kebahasaan. Tindakan membaca karya sastra yang dikombinasikan dalam penerapan teknik transformasi teks puisi dan co-creative writing dapat membantu mengurangi kesalahan-kesalahan teknis dalam penulisan. Hal ini sejalan dengan hasil penelitian Bartan (2017: 59) bahwa membaca dalam aktivitas menulis memiliki dampak positif pada keterampilan menulis cerita pendek, terutama dalam hal penggunaan bahasa, isi, pengorganisasian, dan kemampuan komunikasi.

\section{SIMPULAN}

Hasil penelitian tindakan ini menyimpulkan bahwa penerapan teknik transformasi teks puisi dan co-creative writing dapat meningkatkan efikasi diri mahasiswa, mengembangkan kesadaran kolaborasi dalam menulis cerita pendek, dan membangun suasana perkuliahan menulis sastra yang aktif dan dinamis. Peningkatan tersebut terjadi karena teknik transformasi teks puisi dan cocreative writing membuka peluang untuk saling bertukar ide, pengalaman, dan informasi di dalam kelompok. Teknik ini juga membangun suasana pembelajaran yang lebih dinamis. Selain itu, kolaborasi dalam menulis membuka kesempatan pada mahasiswa untuk berpartisipasi lebih aktif dalam kelompok. Teknik transformasi teks puisi dan co-creative writing juga mendorong mahasiswa untuk mengaktifkan kognisi dan daya imajinasi mahasiswa secara kolaboratif.

Peningkatan skor rerata setiap aspek kompetensi menulis cerita pendek dari siklus ke siklus memperlihatkan bahwa penerapan teknik transformasi teks puisi dan co-creative writing dapat meningkatkan kompetensi menulis cerita pendek di kalangan mahasiswa. Teknik ini terutama sangatmembantudalammengembangkan kemampuan untuk menggali ide dan imajinasi penulisan cerita pendek. Mahasiswa menjadi terlatih untuk melakukan ekspansi cerita, modifikasi dan variasi, atau konversi cerita. Selebihnya, teknik ini juga mampu 
meningkatkan kemampuan mahasiswa dalam merancang alurcerita, menentukan sudut pandang, serta memperbaiki aspek mekanik kebahasaan.

\section{UCAPAN TERIMA KASIH}

Ucapan terima kasih disampaikan kepada teman sejawat yang telah memberi masukan dan saran dalam proses penelitian. Ucapan terima kasih juga disampaikan kepada para mahasiswa yang terlibat sebagai responden dalam kegiatan penelitian.

\section{DAFTAR PUSTAKA}

Ansarimoghaddam, S \& Tan, Bee Hoon. (2018). Co-constructing an Essay: Collaborative Writing in Class and on Wiki, dalam 3L: The Southeast Asian Journal of English Language Studies. 19(1): 35-50. http:// ejournals.ukm.my/31/article/ view/1079

Bandura, A. (1997). Self Efficacy The Exercise of Control. New York: W.H Freeman and Company.

Bandura, A. (2010). Self Efficacy. The Corsini Encyclopedia of Psychology, 2010. Pp. 1-65. http://acmd615. p b w o r k s . c o m / f / S e $1 \mathrm{f}$ efficacydefined.pdf.

Bartan, Ö. S. (2017). The Effect of Reading Short Stories in Improving Foreign Language Writing Skills, dalam The Reading Matrix: An International Online Journal. Volume 17(1): 59-74. https://www. r e s e a r c h gate.net/ publication/315714627_The Effects_of_Reading_Short_Stories_
in_Improving_Foreign_Language_ Writing_Skills.

Burns, A. (2010). Doing Action Research in English Language Teaching: A Guide for Practioners. New York: Taylor and Francis Group.

Chen, W \& Yu, Sh. (2019). Implementing Collaborative Writing in Teachercentered Classroom Contexts: Student Beliefs and Perceptions. Language Awareness. https://doi.org /10.1080/09658416.2019.1675680.

Dimililer, Ç., Kurt, M., Güneyli, A., \& Ulu, EG. (2020). The Effects of the Creative Collaborative Short Story Writing Technique on Developing Teacher Candidates' Writing Skills. folklor/edebiyat. Derg, 26(1), 187-201. DOI: $10.22559 /$ folklor. 1032.

Dobao, A. F., \& Blum, A. (2013). Collaborative Writing in Pairs and Small Groups: Learners' Attitudes and Perceptions. System, 41, 365378 . DOI: $10.1016 / j$. system.2013.02.002

Dörnyei. Zoltán. 2001. Teaching and Researching Motivation. England: Longman.

Khatib, M \& Seyyedrezaei, S.H. (2017). Short Story Based Language Teaching (SSBLT): A literaturebased Language Teaching Method. Journal of Humanities. 1(4): 177-182. Doi: 10.22034/jhi.2017.86977.

Masie, S.R., Siswanto, W., Pratiwi, Y \& Suwignyo, H. (2018). The Literacies Effectiveness of Short Story Writing Learning Model. Journal of Language Teaching and Research, 9(2), 391-397. DOI: http://dx.doi.org/10.17507/ jltr.0902.23. 
Miles, M. B., Huberman, A. M., and Saldana, J. (2014). A Method Sourcebook: Qualitative Data Analysis (3rdEd.). London: Sage Publications, Ltd.

Nurgiyantoro, B. (2010). Penilaian Pembelajaran Bahasa Berbasis Kompetensi. Yogyakarta: BPFE.

Pardede, P. (2011). Using Short Stories to Teach Language Skills. Journal English Teaching, 1(1), 14-27. DOI: 10.33541/jet.v1i1.49.

Rahman, S. \& Arju, S.. (2013). Exploiting Short Stories in the EFL Classroom. Stamford Journal of English, January 2013, p. 124-141. DOI: 10.3329/sje. v4i0.13493.

Riffaterre, M. 1978. Semiotics of Poetry. 'Penciptaan Teks'. London: Routledge \& Kegan Paul.

Sabti, AA., Rashid, S. Md., Nimehchisalem, V., and Darmi, Ramiza. (2019). The Impact of Writing Anxiety, Writing Achievement Motivation, and Writing Self-Efficacy on Writing Performance: A Correlational Study of Iraqi Tertiary EFL Learners. SAGE Open. Journals.sagepub.com/ home/sgo. October-December 2019: $1-13$. DOI: $10.1177 / 2158244019894289$.

Sayuti, S. A., dkk. (2008). Pengembangan Model Pembinaan Menulis Karya Sastra bagi Anak dan Remaja. Jurnal Fenolingua.

Setiartin, T. R. (2016). Transformasi Teks Cerita Rakyat ke dalam Bentuk Cerita Bergambar sebagai Model
Pembelajaran Membaca Apresiatif, dalam Litera Jurnal Penelitian Bahasa, Sastra, dan Pembelajarannya. 15(2), 389-401. DOI: https://doi. org/10.21831/ltr.v15i2.11837.

Storch, N. 2005. Collaborative writing: Product, process, and students' reflections. Journal of Second Language Writing, (14), 153-173. DOI:10.1016/j.jslw.2005.05.002.

Syamsi, K. 2012. Model Perangkat Pembelajaran Menulis Berdasarkan Pendekatan Proses Genre bagi Siswa SMP. Litera, Jurnal Penelitian Bahasa, Sastra, dan Pembelajarannya. 11(2), 288-297. DOI: https://doi. org/10.21831/ltr.v11i2.1070.

Tanyer, S. (2015). The Role of Writing and Reading Self_Efficacy in First Year Preservice EFL Teacher's Writing Performance. Procedia Social and Behavioral Sciences, (199), 38 - 43. https://doi.org/10.1016/j. sbspro.2015.07.484.

Vengadasamy, Ravichandran. 2002. Responding to Student Writing: Motivate, Not Criticise, dalam GEMA Online Journal of Language Studies. 2(1), 1-9. http://ejournal. ukm.my/gema/article/view/219

Weigle, S.C. (2002). Assessing Writing. Cambridge: Cambridge University Press.

Wigglesworth, G., \& Storch, N. (2009). Pair Versus Individual Writing: Effects on Fluency, Complexity and Accuracy. Language Testing, (26), $\begin{array}{lllllll}4 & 5 & - & 4 & 6\end{array}$. DOI:10.1177/0265532209104670 